\title{
Health, Disease and Society in Nineteenth Century Lancaster
}

\author{
Simran Dass, Quenton Wessels, Adam M Taylor
}

\section{INTRODUCTION}

Lancaster's unique geographical location affords it a rich cultural, economic and educational history. ${ }^{(1)}$ Human settlement in the area can be traced back to the third millennium B.C. and the presence of humans in the area undoubtedly shaped the town over time. (2) The county town of Lancaster was once a leading port for trade with the West Indies but was detrimentally affected by the Napoleonic Wars. The town's economic decline was further exacerbated by the silting of the Lune, the falling wheat prices between | 818-1822, the opening of Liverpool's port, (3) the collapse of two of the town's banks and the peak in the number of unemployed in 1824. Transatlantic commerce declined and the last recorded ship to dock at St. George's Quay was in 1833. $(3,4)$ Cabinet making by Gillow \& Co. prevailed through these turbulent times and Lancaster's recession fortunately came to an end and trade once more returned to the Lune. The new economic growth was driven by the trade of Baltic timber, Irish grain and coastal, rather than transcontinental, trade through Glasson Dock reinvigorated the town. ${ }^{(3)}$ Lancaster served, in part, as a service and route centre for both North Lancashire and West Yorkshire and this was further aided by the opening of the town rail systems; the North Western in 1829; and the Preston Junction Railway in 1840.

Lancaster steadily continued to develop into an industrial town from 1840 onwards and two family firms, one run by James Williamson and Sons and the other by William and Thomas Storey, provided employment at the canal side mills. ${ }^{(4,5)}$ The provision of medical and social services progressed as well and included the establishment of a Dispensary ( $178 \mid$ ), a County Lunatic Asylum (opened in 1816), the Royal Albert Asylum (opened in 1870), The Royal Lancaster Infirmary, established in 1896 and the successor to the Infirmary at Thurnham Street. The history of these establishments is well documented. (6-9) Two orphanages, Ripley Hospital (opened in 1864) and Nazareth House (opened in 1902) were also established in Lancaster. $^{(4)}$

Historians continue to expand the narrative of the medical landscape in England. Yet, regional and local differences in the development of medicine as a trade remains challenging to describe and the use of generalisations have proved to be of great value in sketching the social history of medicine. ${ }^{(10)}$ Any attempt to portray local medical cultures are worth exploring in their own right and has the potential to link multiple sources and fill existing gaps. ${ }^{(10)}$ In addition, such attempts might provide further insights into regional and local differences in health, perhaps shed light on doctor-patient ratios and explain local mortality rates. The latter were known to be extremely high between 1700 and 1900. $(7,8)$ The aim here is to provide an overview of the general health and disease of the population in Lancaster during the nineteenth century.

\section{DISEASE AND SOCIETY}

The latter part of the eighteenth century in Lancashire was marked by a rapid population growth of many of Lancashire's towns and cities as a result of industrialisation and urbanisation. Lancaster's population gradually increased from the fourteenth century onwards to reach a total of circa 17,000 by 1781. This number included 3,81 I families who lived in 3,657 houses at the time. ${ }^{(1)}$ In fact, the proportionate population growth in Lancaster surpassed that of the other counties in England. The overall expansion of Liverpool and Manchester largely contributed towards this but even with the exclusion of these cities, the county still ranked third in growth from 1790 onwards. ${ }^{(10)}$ The population of Lancaster Township reached a total of 8,580 by 1785 and expansion continued throughout the nineteenth century to reach around 31,224 inhabitants by |90| (Table I). ${ }^{(12)}$

Table I. Estimates of the population of Lancaster Borough, consisting of the Lancaster Township and Lancaster Castle, from I80 I to 190I (adapted from Winstanley, 200 I). (12)

\begin{tabular}{|c|c|c|c|c|}
\hline Year & $\begin{array}{l}\text { Lancaster } \\
\text { Township }\end{array}$ & $\begin{array}{l}\text { Lancaster } \\
\text { Castle }\end{array}$ & $\begin{array}{l}\text { Lancaster } \\
\text { Borough } \\
\text { and Castle }\end{array}$ & $\begin{array}{l}\text { Decennial } \\
\text { Change (\%) }\end{array}$ \\
\hline | 80 | & 9,030 & * & 9,030 & \\
\hline$|8| \mid$ & 9,247 & * & 9,247 & 2.40 \\
\hline | 82 | & 10,144 & * & 10,144 & 9.7 \\
\hline | $83 \mid$ & 12,167 & 446 & $12,6 \mid 3$ & 24.35 \\
\hline | $84 \mid$ & $|3,53|$ & 558 & | 4,089 & 11.70 \\
\hline | $85 \mid$ & |4,378 & 226 & |4,604 & 3.66 \\
\hline | 86 | & | 4,324 & 163 & | 4,487 & -0.80 \\
\hline | 87| & 17,034 & 211 & 17,245 & 19.04 \\
\hline | $88 \mid$ & 20,558 & 105 & 20,663 & 19.82 \\
\hline | 89| & 26,380 & 61 & 31,038 & 50.21 \\
\hline $190 \mid$ & 31,224 & 64 & 40,329 & 29.93 \\
\hline \multicolumn{5}{|c|}{$\begin{array}{l}\text { Table I. Estimates of the population of Lancaster Borough, consisting } \\
\text { of the Lancaster Township and Lancaster Castle, from 1801 to } 1901 \\
\text { (adapted from Winstanley, 2001). } \\
\text { *(Th) } \\
\qquad 1801 \text { to } 1821 \text { ) }\end{array}$} \\
\hline
\end{tabular}


Edwin Chadwick (| 800-1890) appropriately stated that the history of Britain's towns, during the first half of the nineteenth century, is largely the history of tuberculosis and typhus. ${ }^{(13)}$ The towns and cities of England had higher mortality rates compared to the countryside..$^{(14)}$ Lancashire, during the period | 760-1840, is thought to have higher mortality rates compared to other counties and the most important diseases included typhus (putrid fever or gaol fever), influenza, typhoid and whooping cough. ${ }^{(15)}$ Evidence suggests that one contributing factor for these high mortality rates is general poor health that plagued various families throughout the county. ${ }^{(10)}$ Health problems typically affected numerous members of any given family and not even the medical professionals were spared. The Turner family of Lancaster at Friar Street serves as an example. Sir William Turner (1832-1916), the famous anatomist and later Principal of Edinburgh University, was one of four children and the only child of William Turner senior and Margaret Turner to reach adulthood. ${ }^{(16)}$ William's older brother, also named William, died after birth and it was not uncommon for two members of the family to receive the same name in the event that one dies during infancy, Turner's younger siblings, Mary Ellen (| 834-| 838) and Robert (| 836-|85|) succumbed to diphtheria and erysipelas respectively, ${ }^{(17)}$

Additional insights to the health of Lancaster's residents come from the Dispensary records which were established in 1781 as a result of the efforts of David Campbell (1749-|832), a local physician and founder of the Lancaster Medical Book Club. ${ }^{(18)}$ One report, published in the Lancaster Gazette on Saturday 08 May 1 819, stated that "I 86 patients were admitted on the books of this Institution (Lancaster Dispensary) last month" and 56 patients were vaccinated. The report continues to state that there were 22 cases of typhus and one case of scarlet fever. ${ }^{(19)}$ The first 18 years of the Dispensary's existence saw a total of 22,032 patients treated. The outpatients were treated for a range of ailments and records show that included the typical medical conditions of the time included quinsy (peritonsillar abscess due to tonsillitis), croup, erysipelas ("holy fire", and "St. Anthony's fire" which is an acute Streptococcal infection of the skin), chronic weakness, palsy, hysteria, colic, gravel (urinary calculi which comprises kidney stones, stones in the ureters and bladder), dropsy (oedema), scrofula (probably non-pulmonary Tuberculosis), scurvy, coetaneous disorder (general diseases of the skin), worms, cancerous tumours or scirrhous, and convulsions. The Dispensary aimed at the provision for the "sick poor with medical advice and medicine gratis", (II)

Lancaster's House of Recovery (HoR) or Fever Hospital soon followed as a result of the growing need to treat inpatients to serve those affected with febrile diseases or surgical patients. A house at Plumb Court (now demolished) was purchased for this purpose and was transformed to accommodate five patients and Christopher Johnson ( I782- | 866), a local surgeon, is largely credited for these efforts. Johnson, on 22 July I 822, arranged a meeting in order to establish a Board of Health to serve the town as a charity and to establish the HoR. Anderson writes that physicians of the day showed a lot of interest in fever diseases. ${ }^{(20)}$ This is particularly true for David Campbell and Lawson Whalley (|782-|84I). The property was situated at the end of Sulyard Street what is known today as Bulk Street. ${ }^{(11,20)}$

Acute infections appeared to be a major burden that plagued many communities of early modern England and seemed to persist well into the nineteenth century (Table 2) and

\begin{tabular}{|c|c|c|c|c|c|c|c|c|c|c|c|c|}
\hline \multirow{3}{*}{$\begin{array}{l}\text { Counties and } \\
\text { towns }\end{array}$} & \multicolumn{10}{|c|}{ Number of Deaths during the Year ended $31^{\text {st }}$ December, 1838 from: } & \multirow{3}{*}{$\begin{array}{l}\text { Proportion } \\
\text { of deaths } \\
\text { from } \\
\text { preceeding } \\
\text { causes in } \\
\text { every } 1,000 \\
\text { of the } \\
\text { population } \\
\text { in }|84|\end{array}$} & \multirow{3}{*}{$\begin{array}{l}\text { Proportion } \\
\text { of deaths } \\
\text { from all the } \\
\text { causes of } \\
\text { mortality } \\
\text { in every } \\
1,000 \text { of the } \\
\text { population } \\
\text { in } 1841\end{array}$} \\
\hline & \multicolumn{4}{|c|}{$\begin{array}{l}\text { I. } \\
\text { Epidemic, Endemic, } \\
\text { and Contagious Diseases }\end{array}$} & \multicolumn{3}{|c|}{$\begin{array}{l}2 . \\
\text { Diseases of } \\
\text { Respiratory Organs }\end{array}$} & \multirow{2}{*}{$\begin{array}{l}3 . \\
\text { Diseases } \\
\text { of Brain, } \\
\text { Nerves, } \\
\text { and } \\
\text { Senses }\end{array}$} & \multirow{2}{*}{$\begin{array}{l}4 . \\
\text { Diseases } \\
\text { of } \\
\text { Digestive } \\
\text { Organs }\end{array}$} & \multirow{2}{*}{$\begin{array}{l}\text { Total deaths } \\
\text { resulting } \\
\text { from the four } \\
\text { preceding } \\
\text { Classes of } \\
\text { Diseases }\end{array}$} & & \\
\hline & 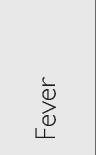 & 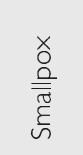 & $\begin{array}{l}\frac{\tilde{0}}{\tilde{N}} \\
\frac{\mathbb{U}}{\Sigma}\end{array}$ & 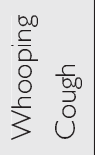 & 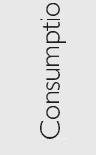 & 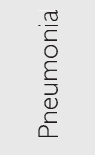 & 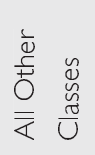 & & & & & \\
\hline Bedford & 115 & 75 & 40 & 66 & 457 & 97 & 57 & 304 & $|3|$ & 1,382 & 13 & 22 \\
\hline Cambridge & 231 & 136 & 57 & 90 & 686 & 156 & 70 & 318 & 189 & 1,933 & 12 & 21 \\
\hline Chester & 592 & 279 & 178 & 87 & 1,742 & 366 & 345 & ।,442 & 421 & 5,452 & 14 & 21 \\
\hline Lancaster & 2,866 & 1,628 & 898 & 910 & 8,124 & 2,660 & 1,916 & $/, 45 /$ & 3,231 & 29,690 & 18 & 25 \\
\hline Middlesex & 4,422 & 3,359 & 487 & 1,749 & 6,220 & 3,097 & 2,334 & 6,643 & 2,492 & 30,803 & 20 & 27 \\
\hline Nottingham & 222 & 73 & 18 & 80 & 911 & 225 & 201 & 901 & 287 & 2,918 & 12 & 20 \\
\hline Oxford & 222 & 81 & 51 & 59 & 655 & 108 & 152 & 389 & 180 & ।,897 & 12 & 21 \\
\hline Surrey & ।,348 & 814 & 177 & 565 & 2,196 & 978 & 700 & 2,325 & 763 & 9,866 & 11 & 25 \\
\hline Warwick & 454 & 415 & 153 & 164 & I,495 & 678 & 361 & 978 & 635 & 5,336 & 13 & 20 \\
\hline Westmorand* & 41 & 40 & 6 & 41 & 248 & 33 & 44 & 154 & 46 & 653 & 12 & 21 \\
\hline Worcester & 381 & 305 & 122 & 258 & 990 & 353 & 235 & 645 & 446 & 3,735 & 16 & 29 \\
\hline & *We & 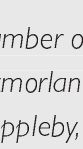 & N & Is & yect & . & . & . & a vari & tiseases in & $\begin{array}{l}\text { ted coun } \\
\text { wards: } \\
\text { Shap, Yar }\end{array}$ & \\
\hline
\end{tabular}


Chadwick's report of 1842 highlights Lancaster as one of the towns with a very high mortality rate. More than 8, 124 fatalities were recorded due to consumption or tuberculosis and fevers claimed the lives of 2,866 individuals. In addition, a large proportion of the deaths were caused by gastro-enteric infections such as typhoid, dysentery and undifferentiated diarrhoeas. Respiratory ailments included scarlet fever, influenza, diphtheria, whooping-cough and typhus (Table 2). ${ }^{(13)}$

Tuberculosis was deemed the most deadly disease of its time, and a particular threat to the working-class. ${ }^{(21,22)}$ It was more prevalent in certain towns in Northern England than others and Lancaster was particularly notorious for this disease. Even by the end of the Victorian era, tuberculosis caused $6.8 \%$ of all deaths per year in Lancaster, ${ }^{(23)}$ Despite this, the decline in TB over the period was great, and this paired with the improvements in the public health of Lancaster were often credited to the Lancaster Medical Officers of Health $(\mathrm{MOH})$ who took action in improving healthcare. ${ }^{(24)}$ The aims of the $\mathrm{MOH}$ were to increase the confidence of the working-class towards hospitals and doctors, gradually altering their beliefs from humorism to cellular pathology, in addition to lowering mortality rates in Lancaster. ${ }^{(23)}$ From | 85 | to | 870 (Table 3) there was a slight decline in the annual mortality from tuberculosis per thousand; however from 1870 there was a rapid decline until 1910 . This is due to the fact that most sanitary reforms and the majority of medical knowledge that influenced these reforms occurred from 1870 onwards. (21) Ninety people died from TB in 1885 and this number declined to nine documented cases, gastro-enteric infections claimed 38 and diphtheria and measles resulted in 23 and 17 fatalities respectively, ${ }^{(8)}$

In addition to sanitation, Cronje in 1984 writes that diet, work, and the quality of milk had a large effect on mortality rates. ${ }^{(25)}$ According to the 1863 Privy Council Survey, the disparities in tuberculosis mortality rates were related to the average diet in different regions of England and Wales. At the beginning of the era, sanitary conditions were unfavourable and diseases were prevalent. Therefore, examining the diet of Lancastrians is essential in order to obtain a valid account of the tuberculosis decline in Victorian Lancaster.

\section{During the Victorian era, Lancaster had two major} trades: linoleum and oilcloth. As men worked in crowded environments that involved lots of contact with other people, they contracted tuberculosis much easier and more often than women and children. ${ }^{(26)}$ These two firms hired many of the working-class in Lancaster, and the average salary was less than one pound a week. ${ }^{(23)}$ According to Oddy, 30 shillings was enough to feed a family of four for a week, however in Lancaster the average family size was either double or triple this amount, causing financial constraints involving feeding the entire family. (27) However, Lancaster was shown to be 'healthier' than other regions in England and Wales, indicating

\begin{tabular}{|l|c|c|c|c|c|c|c|c|c|c|}
\hline & \multicolumn{2}{|c|}{$|85|-60$} & \multicolumn{2}{|c|}{$|86|-70$} & \multicolumn{2}{|c|}{$|87|-80$} & \multicolumn{2}{|c|}{$|88|-90$} & \multicolumn{2}{|c|}{$|89|-1900$} \\
\cline { 2 - 12 } & $M$ & $F$ & $M$ & $F$ & $M$ & $F$ & $M$ & $F$ & $M$ & $F$ \\
\hline Lancashire & 4.2 & 4.0 & 4.0 & 3.6 & 3.6 & 3.0 & 3.0 & 2.4 & 2.6 & 2.0 \\
\hline Worcestershire & 2.6 & 2.8 & 2.3 & 2.2 & 2.2 & 1.9 & 2.0 & 1.6 & 1.9 & 1.3 \\
\hline
\end{tabular}

Table 3: Annual tuberculosis death rates per thousand among males and females in Lancashire and Worcestershire Registration Counties, 1851 -1910 (Woods, 1984). ${ }^{2}$ that either the diet of Lancastrians was better or income was coming from other sources. ${ }^{(25)}$ Records (1797) from the Union Workhouse, built in 1788 on the south side of Quernmore Road, lists milk pottage, bread, broth, beef and vegetables, oatcake leavened and a hash made of any unconsumed meat of the week as elements of the weekly diet of the inmates. (28) The diet of Lancastrians consisted of potatoes, bread, milk, and meat on average once a week. The routine consumption of vegetables and fruit was uncommon until the 1900s. The River Lune running through Lancaster was another source of nutritious food: cockles and eels could be found occasionally, providing a good source of protein. ${ }^{(26)}$

\section{LANCASTER'S EPIDEMICS}

Insights to the epidemics and fevers that plagued the town come from the work of Fleury and others. ${ }^{(|3,29-3|)}$ Fleury states that Lancaster was last plagued with a serious smallpox epidemic in November 1755 when 200 individuals sadly died. ${ }^{(30)}$ David Campbell gained extensive experience in 1782, 1783, and 1784 on typhus, both in Lancaster and the adjacent mill villages. ${ }^{(32)}$ Campbell would later gain repute for his forthright claims on the contagion of typhus and influenza during a period known for its disputes on the causality of disease. ${ }^{(23)}$ Campbell argued that influenza was indeed contagious and ran its course through families and different regions of England. (33) Campbell alone reported 500 typhus cases in Lancaster with 94 of them being children under 14. The mortality amongst the adults was 7.6\%. At the cotton mill at Backbarrow, 20 miles away, all | 3 | children survived but the mortality in 49 adults was $14 \%$, $^{(29,32)}$ Of particular interest is the case of the son of Henry Bracken ( 1697- 1764), a local surgeon and man-midwife, who died of typhus as an apprentice whilst serving the inmates at Lancaster Castle. ${ }^{(34)}$

Smallpox and influenza afflicted the town like most of the others in the county. An outbreak of smallpox occurred in November 1755 and 200 individuals perished. ${ }^{(30)}$ Lancaster suffered several severe cases of influenza. The first account, as documented by Campbell, was in 1775 after its progress from London to the North and reached Lancaster three days after it had struck Liverpool. ${ }^{(33)}$ The epidemic continued to spread north to reach Aberdeen by the end of November and prevailed for five weeks. ${ }^{(35)}$ The second was in |890-9| when the influenza epidemic was said to be dominant. ${ }^{(30)}$

Cholera reached the shores of England and occurred in October 183 I when a ship carrying sailors who had the disease, docked at Sunderland. It would take several months for the disease to finally reach London in 1832. Lancaster wasn't spared and a total of I 4 individuals died (Table 4). Fleury writes that there was a severe attack of cholera in the town and County Asylum (Lancaster County Lunatic Asylum) from 1832 to $1834 .{ }^{(30)}$ The same year saw the amalgamation of the Dispensary and HoR to form the Infirmary at Thurnham Street.(I) The epidemic first appeared at the County Asylum in September in 1832 and 246 cases were reported. A total of 94 individuals, aged between 24 to 84 years, died and 5 deaths were recorded in the town (Table 4). Fleury writes that there were so many coffins in the wards during this period that the doctor, Lawson Whalley, had to stride over them. ${ }^{(30)}$ Whalley was best known for his outstanding contribution to combating 
the 1832 cholera epidemic in Lancaster. ${ }^{(31)}$ The workhouse housed 152 inmates at the time (Table 4); 29 cases and I 5 deaths were documented, 10 of which were children under the age of 12. Cholera struck the town again in 1849 and claimed the lives of 17 people. ${ }^{(30)}$

\begin{tabular}{|l|c|c|}
\hline & Total Cases & Total Deaths \\
\hline Town & 5 & 5 \\
\hline Workhouse & 29 & 15 \\
\hline Asylum & 246 & 94 \\
\hline Total & 280 & 114 \\
\hline
\end{tabular}

Table 4. The total number of cases and the death toll of the Lancaster cholera outbreak of 1832 (adapted from Howson, 2003).

The public health movement of the nineteenth century, in part driven by the cholera epidemic was another agent of change aimed at cleaning up the towns of England and Lancaster.

The Old Poor Law and its provisions proved inadequate and cholera provided a new urgency for change. The efforts of Sir Richard Owen (| 804- | 892) and Edmund Sharpe (| 809- | 877), a local architect, proved invaluable during Lancaster's Sanitary Reform. ${ }^{(35,36)}$ Owen was appointed as a member of the
Health of Towns and the result was the introduction of a piped water supply (Fig. IA) as well as a sewage system after the submission of his report in 1844 . In addition, Owen called for the establishment of a new cemetery to the periphery of the town in order to prevent any outflow into the groundwater. Owen and Chadwick at the time were proponents of the miasma theory of disease.

The miasmic theory, the idea that bad or corrupt air is the cause of illness, provided an explanation on the cause of disease for many, ${ }^{(35)}$ One specific anecdote relates to the persistence of the miasmic theory and involves the planting of trees, upon recommendation of the $\mathrm{MOH}$, throughout the town in order to channel any disease-ridden air upwards. ${ }^{(8)}$

A wash-house and public baths were opened in 1863 in addition to the provision of clean water. ${ }^{(8)}$ The majority of yards and courts were notorious for their deplorable conditions (Fig. I A and B), were gradually demolished by either the turn of the century or during the first half of the twentieth century.

\section{CONCLUSIONS}

The nineteenth century in Lancaster was marked by the gradual rise of hospital medicine from the humble origins of the Dispensary to the opening of the Royal Lancaster Infirmary. Another major change in the medical landscape was the public health movement as the efforts of the local $\mathrm{MOH}$.

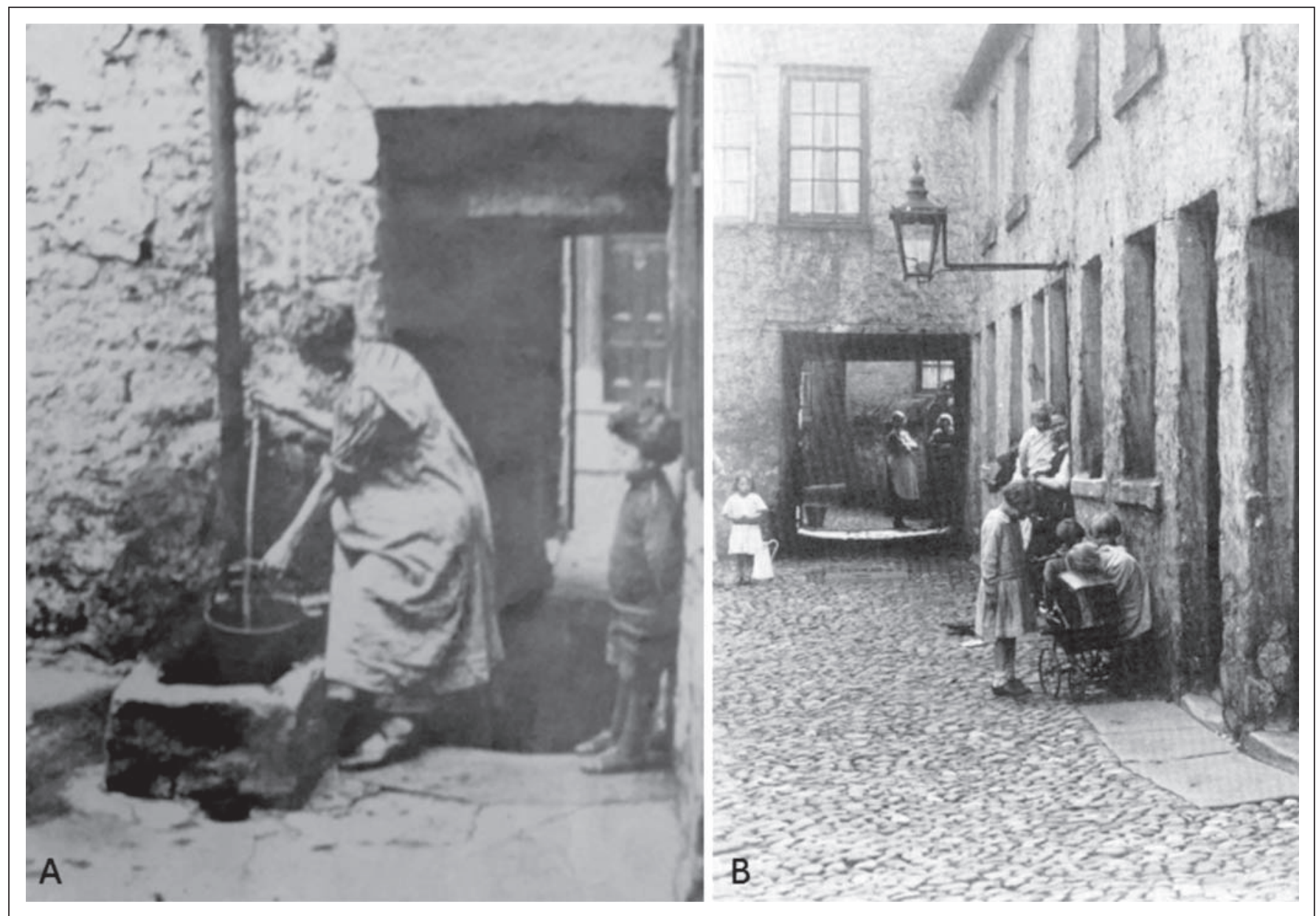

Fig. I.A:The introduction of a piped water supply and communal taps throughout Lancaster ensured safe drinking water (East Court, St. Leonard Gate, c. 1900s). B: The majority of courts and yards, known for their poor sanitation, were demolished over time (Picture postcards of St Mary's Place c. 1900s). 
The $\mathrm{MOH}$ gained power and authority due to the Medical Register being created in 1858 and they were able to vaccinate and isolate patients in accordance with the public health acts ranging between 1858 and 1875 . Alongside these activities, the rates of infectious diseases were decreased by improving the overall sanitation through a number of measures, such as the demolishing of unhygienic yards and courts, the introduction of a piped water supply, and raising awareness of procedures such as boiling milk in an effort to eliminate bovine tuberculosis. These improvements came at the height of the debate around the causation of disease and although it would remain elusive until the germ theory of disease, they nonetheless had a profound impact. The benefits of these improved standards of living were recognised by the public, and confidence in modern healthcare increased, causing the public to take the initiative in activities such as reporting their own diseases. Diet heavily affected the health of the working-class; however as the diet of Lancastrians remained fairly constant until the mid-1900s, this was not a major factor that contributed to tuberculosis decline. The local medical community responded with the establishment of the various centres of care, the Lancaster Dispensary, House of Recovery and later the Royal Lancaster Infirmary, through the agency of the New Poor Law. These developments, in theory, provided the poor of the nineteenth century with more access to medical treatment.

\section{REFERENCES}

I. Sparks J. Lancaster Through Time. Stroud: Amberley Publishing, 2012.

2. Penney SH. Lancaster:The Evolution of its Townscape to 1800. Centre of North-West Regional Studies: University of Lancaster, 1981, pp.9-32.

3. Russell CA. Lancastrian Chemist:The early years of Sir Edward Frankland. Open University Press: Milton Keynes, Philadelphia, 1986; pp.70-72.

4. Price J. Sharpe, Paley and Austin. A Lancaster Architectural Practice 1836-1942. Centre of North-West Regional Studies: University of Lancaster, 1998; pp. 14 - 19.

5. Janes DC. Old towns and Cities: Lancaster. North Yorkshire: The Dalesman Publishing Company Ltd, 1974. pp.48-64.

6. Walton JK, Hogg A, Hurley L. Lancaster Asylum in the I850s and 1860s: Patients and Treatment. Lancaster and Westmorland Medical Journal, 1990; I (3):74-76.

7. Roberts E.The Royal Albert Hospital: An Introduction. In: The Royal Albert: Chronicles of an Era. Centre for NorthWest Regional Studies: University of Lancaster, 1992. pp. I-3.

8. Williamson P. "Your Very Good Health!' Celebrating 50 years of the National Health Service in Lancaster and Morecambe area. Lancaster: 3S Marketing Limited, 1998.

9. Williamson P. From confinement to community: the moving story of 'The Moor', Lancaster's County Lunatic Asylum. Lancaster; Bay community NHS Trust, 1999.

10. King S, Weaver A. Lives in many Hands: The Medical Landscape in Lancashire, 1700-1820. Medical History, 2000;45: 173-200.

I I. Blacktop JG. In Times of Need. The History and Origin of the Royal Lancaster Infirmary. Paperback 1995. Privately Printed; I st edition, 1995.

12. Winstanley M.The Town Transformed, |8|5-19|4. In: A
History of Lancaster. Edited by Andrew White. Edinburgh: Edinburgh University Press, 2001, p. 173-288.

13. Chadwick E. The Sanitary Condition of the Labouring Population of Great Britain. In the Introduction by Flinn M. W. to the 1965 edition. Edinburgh: Edinburgh University Press, 1842.

14. Wear A. Knowledge and practice in English Medicine, I5591680. Cambridge: Cambridge University Press, 2000. p. 12.

15. King S. A Fylde country practice. Medicine and Society in Lancashire, 1760- | 840. Centre for North-West Regional Studies: University of Lancaster, 200 I,pp.42-58.

16. Wessels Q, Correia JC, Taylor AM. Sir William Turner (1832-1916) - Lancastrian, anatomist and champion of the Victorian era. Journal of Medical Biography 2015 March 3;0(0): $1-7$.

17. Turner AL. Sir William Turner K.C.B. F.R.S., Edinburgh and London: William Blackwood and Sons, 1919.

18. Pickstone JV. Medicine and Industrial Society: History of Hospital Development in Manchester and Its Region, I7521946. Manchester: Manchester University Press; 1986.

19. Lancaster Gazette, 08 May 1819.

20. Anderson GH.The house of recovery and the board of health - from the archives of the Lancaster Medical Book club. Lancaster and Westmorland Medical Journal 1995;2(4):84-86.

2 I. Woods R. Mortality Patterns in the Nineteenth Century. In. R. Woods and J. Woodward (eds) Urban Disease and Mortality in Nineteenth-Century England. London, 1984 pp.37-64.

22. Porter D. Health, Civilization and the State: A History of Public Health from Ancient to Modern Times, London and New York: Routledge, 1999.

23. Beier LM. For Their Own Good (The Transformation of English Working-Class Health Culture, I880-1970). Columbus: The Ohio State University Press, 2008.

24. Wohl AS. Endangered Lives: Public Health in Victorian Britain. Cambridge, MA: Harvard University Press, 1983.

25. Cronje G. Tuberculosis and Mortality Decline in England and Wales, I85 I-1910. In Woods R and Woodward J (eds.), Urban Disease and Mortality in Nineteenth-Century England. London: Batsford Academic and Educational. I984, pp.79- 101 .

26. Sanitary Institute of Great Britain. Transactions of the Sanitary Institute of Great Britain. London: Sanitary Institute; 1884.

27. Oddy DJ. Working Class diets in the nineteenth century Britain. The Economic History Review, 1970: 314325.

28. Eden FM. The State of the Poor; Or, An History of the Labouring Classes in England, from the Conquest to the Present Period. London: Printed by J Davis, 1797.

29. Campbell D. Observations on the typhus: or, low contagious fever, and on the means of preventing the production and communication of this disease. Lancaster: H. Walmsley, 1785.

30. Fleury C.Time-honoured Lancaster: Historic notes on the ancient borough of Lancaster. Lancaster: Eaton \& Bulfilld, |89|. 
31. Howson G.The Cholera outbreak of 1832 in Lancaster. Contrebis 2003; 28: 42-45.

32. Creighton C.A History of Epidemics in Britain. From the Extinction of Plague to the present time. (Volume II of II). Cambridge: Cambridge University Press. 1894; p. I 44- 152.

33. DeLacy M. The conceptualization of influenza in eighteenthcentury Britain: specificity and contagion. Bulletin of the History of Medicine, 1993;67( I):74- | | 8.

34. Harley D. Ethics and Dispute Behavior in the Career of Henry Bracken of Lancaster: Surgeon, Physician, and Manmidwife. in Baker R, Porter D, PoerterR. (eds). The Codification of Medical Morality, Kluwer Academic publisher, |993, 47-7|.

35. Skene G. letter to Fothergill in Thompson, T. ( I 852). Annals of influenza or epidemic catarrhal fever in Great Britain from 1510 to 1837. London: Sydenham Society, p. I I 2.

36. Owen R. Health of towns commission report on the State of Lancaster. London:W Clowes and Sons, 1845.

37. Sharpe E. A history of the progress of sanitary reform in the town of Lancaster from I 845 to 1875; And an account of its water supply, Lancaster: E \& JL Milner, 1876. 